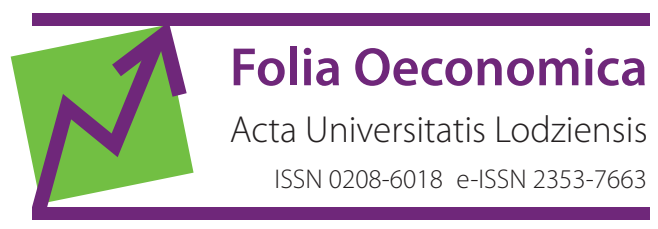

www.czasopisma.uni.lodz.pl/foe/

5(344) 2019

DOI: http://dx.doi.org/10.18778/0208-6018.344.05

\title{
Sławomir Pytel
}

University of Silesia, Faculty of Earth Sciences, Department of Regional Geography and Tourism slawomir.pytel@us.edu.pl

\section{Iwona Kiniorska}

Jan Kochanowski University in Kielce, Faculty of Mathematics and Natural Sciences

Institute of Geography, iwona.kiniorska@ujk.edu.pl

\section{The Socioeconomic Status of Polish Pensioners Before and After Migration}

\begin{abstract}
The aim of this paper is to describe the socioeconomic status of migrating seniors before and after migration. This analysis will enable us to determine whether the overall effect of their migrations is a positive one or a negative one. In order to determine subjective reasons for migrations, questionnaire surveys are used. An analysis of the responses allows us to compare the migrants' living conditions before and after migration with a view to confirming or rejecting Wolpert's (1965) assumptions and to describe the role of migrations in meeting pensioners' needs. Our study confirms the approach of Wolpert (1965), assuming that the behaviour of migrants, including migrating pensioners, is determined by place utility, i.e. the sum of advantages to be obtained by the migrant. The pensioners who migrated are well-off, our respondents report that they are able to meet all their needs if spending money prudently.
\end{abstract}

Keywords: migration of pensioners, economic situation of pensioners, housing situation of pensioners, family situation of pensioners

JEL: J14 


\section{Introduction}

Retirement is a crucial turning point in life. A person finishes his/her economic activities and enters a period when a great deal of leisure time is available. Many people seek a better life after retirement, which manifests in a number of ways, including migration. Migrants want to improve their material and non-material living conditions. For seniors, economic reasons or getting married play minor roles as migration drivers. What pensioners are most likely to desire is a house with a garden. When their health deteriorates, they seek good care. Life before and after retirement is usually totally different. The same can be said about migration, it causes a very major change in one's life.

In order to properly account for the reasons that motivate pensioners to migrate, we need to specify the migrant's socioeconomic status, as it has a crucial impact on his/her needs and wishes. Migrations of seniors also depend strongly on their health, which may deteriorate quickly. All these factors contribute to the final decision to migrate.

The aim of this paper is to describe the socioeconomic status of migrating seniors before and after migration. This analysis will enable us to determine whether the overall effect of their migrations is a positive one or a negative one.

When deciding on possible migration, seniors assess their present situation and compare this assessment with their expectations, as finally it is the cumulative effect of all the advantages offered by a given place that counts for them. This is accounted for, among others, by Wolpert (1965). He argues that decisions to migrate, also the ones taken by seniors, are based on several factors: the perceived place utility, potential migrants' aspirations, space for activity and the life course stage. For Wolpert, the place utility is the sum of advantages to be obtained by the migrant as a person wishing to ensure the appropriate level of needs fulfilment. If this level is not reached, the migrant will look for a new space of activity. This search differs considerably depending on the migrant's age and life course stage.

Migrations of pensioners have an important social aspect. Gaining knowledge on the factors that drive such migrations is crucial for effective functioning of small and medium-sized communities, as senior migrants influence the living conditions, life quality, healthcare and many other spheres of life, and migration policies should be shaped accordingly.

Research on migrations of Polish pensioners is not undertaken often (Kurek, 2006; 2014; Kałuża, 2007; 2008; Jankowski, Pytel, 2013; Kałuża-Kopias, 2013; 2014; Pytel, 2014a; 2014b; 2017; Pytel, Szkup, 2014; Pytel, Ociepka, 2016), the relevant literature published abroad is also scarce (Walford, Kurek, 2008; Kurek, 2011).

The existing literature by authors from various countries devotes a great deal of attention to the problems, process and phenomena of pensioner migrations and related socio-economic transformations (Warnes, 1994; Longino, 1995; King, 
Warners, Wiliams, 1998; Warnes et al., 2004). Reasons for migrations and migration patterns were discussed by Steinnes and Hogan (1992), Krout et al., (2002), as well as Cowper et al. (2000). Migration factors were also explained in many other studies from various regions of Europe, among which the most important ones include Wiseman (1980), Cowper and Corcoran (1989), Colsher and Wallach (1990), Warnes (1993), Walters (2002), Schiamberg and McKinney (2003), La Parra and Mateo (2008), Buffel and Phillipson (2011), Clark and Lisowski (2017).

Research and literature surveys related to migration contributed to the emergence of migration patterns which were proposed by numerous authors often representing diverse scientific disciplines (Litwak, Longino, 1987; Cuba, Hummon, 1993; Haas, Serow, 1993; Quandango, 2002; Warnes, Williams, 2006; Uren, Goldring, 2007).

Many authors (Longino et al., 1991; Hogan, Steinnes, 1993; Marjavaara, Lundholm, 2016) explain migrations by possession of second homes, which are usually located far from cities. The above-mentioned studies confirm the hypothesis that a second home may act as a migration trigger later in life.

The economic basis of migrations has been known from times immemorial, and their consequences were scrutinised by numerous authors, especially at the end of the $20^{\text {th }}$ century (Serow, 1987; Haas, Serow, 1993; Longino, 1995; Bennett, 1996; Gordon, Bennett, 1996; Day, Barlett, 2000).

The analysed issue can also be examined in the context of social exclusion of older people. Social exclusion refers to the separation of individuals and groups from the mainstream of society (Commins, 2004; Moffatt, Glasgow, 2009). It has a multidimensional character and can refer to many areas of life: education, economy, culture, and politics. It may be a lack of access to medical and social services. It may also be the result of restrictions on civil rights. Many concepts of social exclusion were built, and Walsh, Scharf and Keating (2017) wrote about it extensively.

\section{Data and research methods}

In order to determine subjective reasons for migrations, questionnaire surveys are used. An analysis of the responses allows us to compare the migrants' living conditions before and after migration with a view to confirming or rejecting Wolpert's (1965) assumptions and to describe the role of migrations in meeting pensioners' needs. This phenomenon has hardly been subjected to scientific scrutiny in Poland, and nowadays it is becoming more pronounced as the baby boomers of the 1950 s retire.

Primary quantitative research involved gathering information from respondents by means of a standardised questionnaire survey. The research was carried out on a selected sample, and the data from the questionnaires were analysed us- 
ing statistical methods. A database with addresses of pensioner migrants obtained from the Polish Ministry of Internal Affairs served to create the so-called sampling frame containing 37.216 individuals which subsequently underwent further sampling procedures. In this study, stratified sampling was used. It involves dividing the whole population into strata (here provinces) and then selecting randomly independent samples from each stratum. The population was divided into strata so as to ensure that each element belonged to just one stratum. Considering the population size 37.216 , the confidence level $98 \%$, the response distribution $50 \%$, and the maximum margin of error $5 \%$, the required number of respondents amounted to 534. Two thousand questionnaires were sent out and over 550 were actually returned, which amounts to $25 \%$ and constitutes a very satisfactory response rate. It can be assumed that the data from the Central Statistical Office might slightly underestimate the phenomenon, as not every migrant has registered his/her mobility in accordance with the legal regulations. However, this underestimation is probably considerably smaller for pensioners than for working-age migrants.

The questionnaire was sent out to respondents by mail. The envelope contained the questionnaire itself, a return envelope with a stamp to the effect that postage had been paid in advance by the addressee, and a cover letter. The questionnaires were addressed only to pensioners who had moved after retirement. They contained 16 questions on issues such as their financial status before and after migration, their housing situation before and after migration, their family situation before and after migration, and their socio-economic situation after migration.

Any pensioner who had permanently changed his/her place of residence was eligible to take part in the survey. The analysis covers responses from 550 participants, $56 \%$ female and $44 \%$ male. Among the respondents, there is the biggest share of persons who have graduated from secondary school (36.7\%), followed by university graduates (34\%), persons with vocational and primary school education (14\% each), and a very small group of persons who have not finished even primary school $(0.9 \%)$. This shows that mostly persons with high education levels were likely to migrate, as over $70 \%$ were graduates of at least secondary school. As they went to schools in 1960s and 1970s, they needed strong determination to achieve this level of education.

As for the age structure of the respondents, $30 \%$ are between 60 and 64 or 65 and 69 years old. Respondents in the $85+$ age bracket account for $9 \%$. This age structure is similar to the overall one of Polish pensioners (see Table 1). As it is possible to retire earlier than usual in some professions (e.g. soldiers, police officers, teachers, miners), also some pensioners younger than 60 took part in our survey and they account for $2 \%$, representing the smallest age group.

In our study, the structure of the migrants is typical for ageing and highly developed societies, which is reflected by their high education level and a big surplus of women in the elderly population. 
Table 1. The age structure of our respondents compared with the overall shares of people aged 60 in Poland in 2013

\begin{tabular}{|l|c|c|c|c|c|c|c|}
\cline { 2 - 8 } \multicolumn{1}{l|}{} & Under 60 & $\mathbf{6 0 - 6 4}$ & $\mathbf{6 5 - 6 9}$ & $\mathbf{7 0 - 7 4}$ & $\mathbf{7 5 - 7 9}$ & $\mathbf{8 0 - 8 4}$ & $\mathbf{8 5}+$ \\
\hline $\begin{array}{l}\text { Share among the respondents } \\
(\%)\end{array}$ & 2 & 30 & 30 & 13 & 10 & 8 & 9 \\
\hline $\begin{array}{l}\text { Share among Polish pensioners } \\
(\%)\end{array}$ & 7 & 27 & 22 & 14 & 13 & 9 & 8 \\
\hline
\end{tabular}

Source: prepared by the authors on the basis of questionnaire responses and data from the Polish Central Statistical Office (GUS)

Analysis of migrations according to sex shows that women aged 60-64 were the group that migrated most often, while men aged 60-64 account for 29\% (see Table 2). As there are overall more women in the age structure, women were more frequent migrants.

As people age, their mobility decreases. In the $90+$ age group, there are only $1 \%$ of male and $3 \%$ of female migrants (Table 2 ). Men dominate over women when we take into consideration migrations before reaching 60 . This may result from the fact that more men than women work in professions that allow them to retire early (e.g. in the mining industry, the police, the military).

Table 2. The share of male/female migrants across different age groups (\%)

\begin{tabular}{|l|c|c|c|c|c|c|c|c|c|c|}
\hline \multirow{2}{*}{ Sex } & \multicolumn{10}{|c|}{ Age when migrating } \\
\cline { 2 - 12 } & Below 49 & $\mathbf{5 0 - 5 4}$ & $\mathbf{5 5 - 5 9}$ & $\mathbf{6 0 - 6 4}$ & $\mathbf{6 5 - 6 9}$ & $\mathbf{7 0 - 7 4}$ & $\mathbf{7 5 - 7 9}$ & $\mathbf{8 0 - 8 4}$ & $\mathbf{8 5 - 8 9}$ & $\mathbf{9 0 +}$ \\
\hline $\begin{array}{l}\text { Men } \\
(\%)\end{array}$ & 10 & 4 & 11 & 29 & 19 & 11 & 7 & 3 & 5 & 1 \\
\hline $\begin{array}{l}\text { Women } \\
(\%)\end{array}$ & 4 & 4 & 8 & 34 & 20 & 9 & 6 & 7 & 6 & 3 \\
\hline
\end{tabular}

Source: prepared by the authors on the basis of questionnaire responses

When we look at the migrants' age and education at the same time (Table 3), it turns out that people aged 60-64 with secondary school education were the most typical migrants, closely followed by university graduates in the same age group ( $2 \%$ fewer). In total, this accounts for $27 \%$. The situation looks more difficult for people above 80, as they were educated before or during World War II. This is reflected in Table 3, in which we can see that among this age group there are some persons who have not finished primary school. In the $80+$ age group, most respondents have finished only primary school, and there are very few university graduates.

The education level of migrating pensioners is very significant. The more educated they are, the greater their willingness is to migrate after retirement. Migrants with low education levels, on the other hand, move when already very old, which is forced by their deteriorating health. 
Table 3. The share of migrants with specific education levels across different age groups (\%)

\begin{tabular}{|c|c|c|c|c|c|c|}
\hline & \multicolumn{5}{|c|}{ Education level } \\
\hline & & University & $\begin{array}{c}\text { Secondary } \\
\text { school }\end{array}$ & Vocational & $\begin{array}{c}\text { Primary } \\
\text { school }\end{array}$ & $\begin{array}{l}\text { Unfinished } \\
\text { primary } \\
\text { school }\end{array}$ \\
\hline \multirow{10}{*}{$\begin{array}{l}\text { Age when } \\
\text { migrating }\end{array}$} & Below 49 & 2.6 & 2.1 & 1.2 & 0.2 & 0.0 \\
\hline & $50-54$ & 1.4 & 1.0 & 0.5 & 1.0 & 0.0 \\
\hline & $55-59$ & 3.3 & 3.8 & 2.1 & 0.2 & 0.0 \\
\hline & $60-64$ & 12.6 & 14.8 & 2.1 & 2.9 & 0.0 \\
\hline & $65-69$ & 6.2 & 7.6 & 3.8 & 1.4 & 0.0 \\
\hline & $70-74$ & 3.3 & 2.9 & 1.2 & 2.1 & 0.2 \\
\hline & $75-79$ & 2.4 & 1.9 & 1.2 & 0.7 & 0.2 \\
\hline & $80-84$ & 0.7 & 1.2 & 1.0 & 2.4 & 0.0 \\
\hline & $85-89$ & 1.7 & 1.7 & 0.5 & 1.9 & 0.2 \\
\hline & $90+$ & 0.2 & 0.0 & 0.0 & 1.2 & 0.2 \\
\hline
\end{tabular}

Source: prepared by the authors on the basis of questionnaire responses

\section{Results}

\subsection{The migrants' economic status}

Financial independence is a priority for pensioners, allowing them to be self-reliant, to afford high quality healthcare and expensive medicines. After retirement, the income decreases drastically. Pensioners who live on their own are in the worst financial situation. Pensioners who live together with their children are better off, as the costs of living are shared by more persons. Nevertheless, many parents try to leave their children after retirement and live separately. Financial independence also depends on seniors' health and fitness. The necessity to use specialist healthcare generates additional costs.

In order to realistically assess the migrants' economic status, we need to refer to their source of income (see Table 4). Employees are always better off than persons who live off a pension. Before migration, 36\% seniors were gainfully employed, and after migration - only $11 \%$. Before migration, $52 \%$ of seniors received a pension, and after migration $-77 \%$, which means a considerable decrease of income for almost $25 \%$. Even lower income is obtained by seniors who live off a disability pension (about $8 \%$ ) and social benefits (1\%). The share of seniors in the former group remains at roughly the same level after migration (8\%), but the share of those in the latter increases significantly, from $0.7 \%$ to $1.4 \%$. At the same time, it is observable that the share of persons depending on their relatives for income decreases from $1.6 \%$ before migration to $0.5 \%$ after migration. It can be hypothesised that these seniors moved into care homes and started claiming a social benefit. 
Table 4. The migrants' source of income before and after migration (\%)

\begin{tabular}{|l|c|c|}
\hline \multicolumn{1}{|c|}{ Source of income } & Before migration & After migration \\
\hline Wages from employment & 36.3 & 11.4 \\
\hline Pension & 52.1 & 77 \\
\hline Disability pension & 8.6 & 8.4 \\
\hline Social benefit & 0.7 & 1.4 \\
\hline Dependant of his/her family & 1.6 & 0.5 \\
\hline Other & 0.7 & 1.3 \\
\hline
\end{tabular}

Source: prepared by the authors on the basis of questionnaire responses

The economic status, however, does not only depend on the seniors' source of income, but, first of all, on the possibility to meet their needs. The finances of our respondents look good both before and after migration, as over 34\% declare that, by spending money prudently, they are able to meet all their needs (see Table 5 ). Over $26 \%$ report that they are able to afford everything both in their previous and new place of residence. It means that over $61 \%$ of the migrants enjoy high economic status. Low economic status is reported by about $10 \%$ of the pensioners, who say that both before and after migration they can afford food, but paying all the fees is troublesome. About $2 \%$ of the respondents live in utter poverty, as they report that they cannot even afford all the food they need.

In the study entitled "Old Age in Poland" included in the 2012 "Report on the Situation of the Elderly in Poland", $3 \%$ of the respondents said they were highly satisfied with their economic status, $24 \%$ were satisfied, $32 \%$ were not satisfied, and $10 \%$ were very unhappy. As many as $29 \%$ of the respondents could not give a definitive answer. Similar research was carried out by the Institute of the Public Affairs. In their study, $2 \%$ of the respondents reported that their income was too low to live in prosperity, $11 \%$ could afford to live without having to economise, $42 \%$ had an income that would allow them to live a modest life, and $34 \%$ - a very modest life. As many as $11 \%$ reported that their income was not sufficient for a living.

A comparison between the economic status of migrating pensioners and pensioners who did not migrate shows a higher status of the former group. In 2014, the average pension in Poland was PLN 1950, however, the modal value was PLN 1550, with men receiving pensions that were, on average, higher by PLN 700 than those received by women (which results, to some extent, from the fact that women are entitled to retire earlier than men - at 60 instead of 65). The average monthly wages, on the other hand, crossed the threshold of PLN 4000 in the same year.

The analysis of income obtained by pensioners, however, does not give us a full picture of their living standards. For instance, the 2012 "Report on the Situation of the Elderly in Poland" shows that if we calculate the average per capita income in a household, the income of pensioners amounting to PLN 1648 is, in fact, among 
the highest in 2010. Only households whose members were employed in non-manual jobs or self-employed obtained higher average income (PLN 2125 and PLN 1867, respectively). The income differed considerably depending on the pensioner's sex, place of residence and former employment. For example, the average pension paid out by KRUS (i.e. for farmers) was about PLN 1000 in 2014, while the one paid out by ZUS (i.e. for most other professions) was about PNL 1950 at the same time. The structure and amount of expenditure in a household is also important. Pensioners have to cover the costs of healthcare that swallow up as much as $7.9 \%$ of their income (Śmiłowska, 2010). This is the third largest expenditure, after food and housing costs. The finances may also enable the purchase of rehabilitation equipment and adaptation of the flat to the needs of a person who has difficulties in moving around. Migrants who move into their own house lower their costs of living. The money saved may be used to buy medicines or for specialist healthcare.

Table 5. The migrants' economic status before and after migration

\begin{tabular}{|l|c|c|}
\hline \multicolumn{1}{|c|}{ Finances } & $\begin{array}{c}\text { In the } \\
\text { previous place } \\
\text { of residence }\end{array}$ & $\begin{array}{c}\text { In the new place } \\
\text { of residence }\end{array}$ \\
\hline Not enough even for food & 2.3 & 1.2 \\
\hline Enough for food, but hardly for all the fees & 10.7 & 9.1 \\
\hline I have to put money aside to afford more expensive items & 25.6 & 28.1 \\
\hline If I spend prudently I have enough money for everything & 34.9 & 34.9 \\
\hline I have enough money for everything & 26.5 & 26.7 \\
\hline
\end{tabular}

Source: prepared by the authors on the basis of questionnaire responses

\subsection{The migrants' housing situation}

The housing situation is an important factor that may induce a person to migrate. It is not only the size and the type of the flat that play a role, but also the available amenities and equipment. When they age, pensioners become less self-reliant and they spend more and more time at home due to difficulties in leaving it. Having a flat that is adapted to seniors' needs allows them to stay there without problems. The need to take care of heating, emptying of the septic tank or a big garden becomes a burden at a certain age and, consequently, the oldest seniors migrate from a house with a garden to a flat in the city, where they have all the utilities at their disposal. Our research shows (see Table 6) that the majority of the respondents lived in a separate flat both before (62\%) and after they moved (50\%). The second most popular option is living in a house, reported by $31 \%$ of the respondents before migration and $38 \%$ after it. These places provide seniors with what they need most, i.e. peace and quiet, independence and self-reliance. Almost $6 \%$ of our respondents 
lived in a separate room before migration, which still ensured some privacy. After migration, this number rises to $10 \%$. In most cases, these pensioners are single and they live together with their children, helping to raise their grandchildren. Some of the older seniors also move to single rooms in a retirement home.

Table 6. Place of residence before and after migration

\begin{tabular}{|l|c|c|}
\cline { 2 - 3 } \multicolumn{1}{c|}{} & Place of residence before migration & Place of residence after migration \\
\hline House & 31.9 & 38.4 \\
\hline Separate flat & 61.9 & 50.5 \\
\hline Separate room & 5.8 & 9.5 \\
\hline
\end{tabular}

Source: prepared by the authors on the basis of questionnaire responses

The seniors we questioned were more likely to move into houses than flats. We can observe that the share of pensioners living in houses rises from $32 \%$ to $38 \%$ after migration, and the share of pensioners living in flats decreases from $62 \%$ to $50 \%$. After migration, the share of pensioners living in separate rooms also increases (see Table 6).

Table 7 shows a detailed analysis of changes in place of residence the respondents inhabited before and after migration. The seniors who lived in houses before migration reported that half of them chose to live in a flat after migration. This is caused by the comfort ensured by this form of residence. There is no need to take care of heating or the garden, which is advantageous, in particular for older pensioners.

$40 \%$ of the pensioners who lived in a house before migration again chose a house. Usually, the new house is located in the suburbs, has good transport links with the city centre and ensures easy access to all the services a senior may need.

The pensioners living in a house who were widowed, started to suffer from disability and needed care chose to live in a separate room, accounting for $10 \%$ of responses. This is usually a room in a flat or house owned by their family, or in a retirement home.

Among the seniors who lived in a flat before migration, over $53 \%$ chose a flat again, and $40 \%$ moved into a house. A separate room was chosen by almost $7 \%$ of the respondents (see Table 7). Moving to a different flat results from the need to lower the cost of the rent and the utilities by obtaining a smaller flat. Seniors with a low pension seek to economise in this way. Usually they sell their previous, large flat and buy a one- or two-room flat. The money gained may be used for other needs. The well-off pensioners move from old into newly built houses. This group mostly comprises younger pensioners who move directly after retirement. Their new house was usually being built while they were still employed and is situated in the suburbs or on in their place of origin.

Among the seniors inhabiting a separate room before migration, $41 \%$ moved into another room, $37 \%$ into a flat, and over $20 \%$ into a house. The first of these 
options is accounted for by the pensioners who used to live with their children, but their deteriorating health forced them to move into a nursing home.

Moving from a house into a flat may seem to involve a lowering of the living standards, but this is not necessarily the case. Seniors living in a flat do not have to take care personally of the utilities such as heating, as this is usually provided for them. For seniors, the most important asset is to be able to remain self-reliant as long as possible, consequently, they usually choose the type of housing in which their needs can be met.

Table 7. Changes in the place of residence after migration (\%)

\begin{tabular}{|l|l|c|c|c|}
\cline { 3 - 5 } \multicolumn{2}{c|}{} & \multicolumn{3}{c|}{ After migration } \\
\cline { 3 - 5 } \multicolumn{2}{c|}{ Before migration } & House & Separate flat & Separate room \\
\cline { 2 - 5 } & House & 40.4 & 50.0 & 9.6 \\
\cline { 2 - 5 } & Separate flat & 39.9 & 53.2 & 6.8 \\
\cline { 2 - 5 } & Separate room & 20.8 & 37.5 & 41.7 \\
\hline
\end{tabular}

Source: prepared by the authors on the basis of questionnaire responses

The amenities available in the place of residence both before and after migration are satisfactory. Almost all facilities have a separate bathroom, are connected to the waterworks, the sewage system and central heating, $80 \%$ are connected to the gas network. $40 \%$ of the migrants have a garden. Although the changes are small, their living standards on average rose slightly when the respondents moved. More persons now have a separate bathroom, connection to the waterworks and central heating, a garden. Moving to the suburbs sometimes results in a lack of connection to the sewage system and the gas network, however, these migrants obtain a garden. They are mostly the youngest seniors directly after retirement. By contrast, the oldest seniors moving to the city gain central heating, which is very important for the elderly (see Table 8).

Table 8. Amenities available in the place of residence before and after migration (\%)

\begin{tabular}{|l|c|c|}
\hline & Previous place of residence & New place of residence \\
\hline Separate bathroom & 93.5 & 96.5 \\
\hline Waterworks & 93.0 & 94.7 \\
\hline Sewage system & 92.8 & 92.6 \\
\hline Gas network & 76.3 & 75.6 \\
\hline Central heating & 87.0 & 92.1 \\
\hline Garden & 42.6 & 48.6 \\
\hline
\end{tabular}

Source: prepared by the authors on the basis of questionnaire responses

The housing conditions play a crucial role for seniors and they exert a considerable influence on their decisions to migrate. What is important is the size 
of the dwelling, available amenities and how many inhabitants are to share it. In order for seniors to be able to enjoy living there as long as possible, their flat has to possess the necessary amenities. According to the report "Income and Living Standards of the Population of Poland" (2012), 97.7\% of pensioner households have cold running water, $92.7 \%$ - a toilet flushed with running water, and $91.7 \%$ - hot running water. $16.7 \%$ use a stove for heating (EU-SILC, 2012: 109). This report also shows that pensioner households have less domestic appliances and equipment, not because seniors do not have the means to afford them, but because they are not interested in obtaining them. However, many pensioner households reported the possession of not only basic appliances such as a phone, a TV set or a washing machine, but also a computer with a printer and Internet access. About every other pensioner household makes use of the most modern equipment. The report also points out that pensioner households in rural areas are usually less well equipped.

Zrałek (2012) claims that pensioners experience many problems related to housing. The most acute of them are difficulties in covering the costs and in adapting the flat to the limitations resulting from ageing and diminishing strength. In addition, seniors struggle with architectural barriers both inside their own home and in its neighbourhood, such as a lack of a lift, steep stairs and a layout that does not allow for the adaption of the flat to the needs of the disabled.

\subsection{Family status of the migrants}

Nearly half of the pensioners report to be married both before and after migration. These are the persons who moved directly after retirement. The second largest group are singles, whose share amounts to $25 \%$ before migration and decreases to over $23 \%$ after migration. This information is very important for local governments in order to prepare adequate care for seniors. It is still very difficult to obtain a place in a good retirement home, and the costs involved are too high for many. Older pensioners are forced to rely on help from their children or sometimes even unrelated people, as neither they themselves nor their families can afford to pay for a retirement home. The share of seniors who live only with their children increases considerably after migration (by as much as $8 \%$ ). Nearly $2 \%$ live in retirement homes after migration.

Family is precious for seniors, and family values are very important for them. Consequently, many single persons (typically widowed) remarry, which causes a change in their place of residence.

Almost $87 \%$ of caretakers report that they are not ready to consider placing their elderly relatives in a care home, regardless of the situation. $11.6 \%$ of caretakers would consider such a possibility if the health condition of the person under their 
care got worse. Only $1.5 \%$ would consider placing their elderly relatives in a care home even if their health did not deteriorate (Bojanowska, 2012).

Among our respondents, the number of singles decreases, and the number of married persons increases. This is not a very significant change, however, the individual cases show that it is important for the elderly to have someone to share their joys and problems. People who are single face serious emotional strain, as they do not have the same psychological support as married people get from their spouses. For seniors who are married, self-reliance is crucial, so they leave their children if they are able to. The number of seniors who live both with their spouse and their children decreases by nearly $10 \%$. This reflects the fact that directly after retirement married couples move to a separate house or flat, leaving their children in the previous place of residence. Furthermore, we also see a $10 \%$ increase in the number of seniors living only with their children. These are pensioners who had been widowed and felt lonely, or ones who started experiencing problems in everyday life on their own. Women dominate decisively in this group due to the fact that they live longer. The research by EUROFAMCARE shows that this way of taking care of the elderly results from two factors: the demographic structure of the Polish family (many children) and the culturally preferred model of care provided by the closest relatives, at home.

Table 9. Family situation of the migrants before and after migration (\%)

\begin{tabular}{|l|c|c|}
\hline \multicolumn{1}{|c|}{ Family situation } & Before migration & After migration \\
\hline Single & 25.8 & 23.3 \\
\hline Married & 47.0 & 48.1 \\
\hline Married with children & 20.9 & 10.7 \\
\hline With children & 3.5 & 11.9 \\
\hline With distant relatives & 1.2 & 2.1 \\
\hline With unrelated persons & 0.7 & 0.7 \\
\hline In a care home & 0.2 & 1.9 \\
\hline
\end{tabular}

Source: prepared by the authors on the basis of questionnaire responses

\section{Discussion}

In the case of migrations, in order to obtain a wide spectrum, gravity models are highly relevant, in particular Wolpert's model (1965). This model includes the following concepts:

1) place utility,

2) field theory used to explain human behaviours,

3) life cycle used to establish threshold values when a person will seek a new residence. 
Wolpert treats migrations as a form of individual or group adaptation to perceived changes in the environment. He claims that humans consciously behave in a rational way, reacting to differences in the place utility. They gauge the utility of a given place taking into consideration the difficulties related to adaptation and changes. He adds that satisfaction leads to laziness, while dissatisfaction drives people to search for new possibilities.

Our research shows that in Poland over 30 thousand of pensioners who decided to migrate were dissatisfied, with the highest share of persons between 60 and 70. As people age their mobility decreases, only 1\% of the male pensioners and $3 \%$ f the female ones migrated after reaching 90 . The place utility is the most important concept by Wolpert. The place utility is the sum of advantages obtained by an individual due to his/her spatial integration and it may be expressed as a positive or negative quantity reflecting the individual's level of satisfaction or dissatisfaction with respect to a given place.

The obtained results clearly confirm that the housing situation of the pensioner migrants improved. The share of those who lived in their own houses increases, moreover, they gain access to better infrastructure. The sum of advantages obtained by the seniors after migrating is considerable, as housing conditions play a prominent role in the life of the elderly.

As for the field theory used to study human behaviours, Wolpert (1965) argues that although we possess a wide range of information about the environment, only a part of this information is considered when deciding to migrate. He relates to Lewin's (1936) concept of life space.

Our research shows that the life space of many pensioners has changed. Among our respondents, the share of single pensioners decreases while the share of pensioners living together with their spouses increases. Independence is very important for people living with their spouses, so they leave their children if they have such a possibility. The share of pensioners living together with their spouse and children decreases by almost $10 \%$.

Last but not least, Wolpert also developed the concept of the life cycle. It relates to Hägerstrand's (1962) analysis of migration flows through a system of stages, but also to Lewin's (1936) argument that human behaviour is a function of the life space, which, in turn, is a function of an individual and his/her environment.

Our analysis of the migrants' age and education structure shows that the most numerous group consists of pensioners between 60 and 64 with secondary level education. The same age group with higher education is slightly smaller (by $2 \%$ ). If we consider the two education levels together, the 60-64 age group accounts for an over $27 \%$ share among the migrants. For pensioner migrants, their education level plays a very important role. The higher their education level, the more likely our respondents are to migrate after retirement. Migrants with a low education level move when they reach very old age and the migration is forced by their 
deteriorating health. On the basis of Wolpert's concept of place utility and the results obtained by us, we can argue that the place utility of his/her destination is the most important factor for a pensioner. Humans tend to settle in the place selected by the ones they know and possessing or promising to offer the biggest advantages.

\section{Conclusions}

Our research shows that migration is a multifaceted phenomenon that should be considered from a variety of angles. Especially at the time of progressing longevity and society ageing, it is a challenge for local governments, whose task is to enable the elderly to function normally in the community. The social capital represented by seniors is very precious, it should be supported and promoted.

Migrations of pensioners play an important role in the social and economic development of urban and rural areas. They cause income to be transferred to migration destinations, they drive the development of infrastructure needed by seniors and the creation of new jobs related to providing the necessary assistance. On the other hand, they may become a burden for the local social services through an increased need for care, and limit investment by companies who seek new employees.

Our study confirms the approach of Wolpert (1965), assuming that the behaviour of migrants, including migrating pensioners, is determined by place utility, i.e. the sum of advantages to be obtained by the migrant. The pensioners who migrated are well-off, our respondents report that they are able to meet all their needs if spending money prudently. Housing conditions are very important for pensioners, significantly influencing their decisions to migrate. The study shows that the majority of the seniors who migrated live in a separate flat or house. The amenities available to them are satisfactory, with almost all dwellings possessing a separate bathroom and central heating, as well as being connected to the waterworks and the sewage system. Many of the pensioners also have a garden, and their house/ flat is connected to the gas network. Among our respondents, the share of singles decreased and the share of married persons increased.

We can conclude that the pensioners participating in our study improved their living standards by moving to a new place. However, it remains to be seen whether migrations of seniors are a chance for development or a burden for urban and rural areas where they move. This will depend on the social policy, and in particular on efforts undertaken to make the best possible use of the social potential of active, creative and experienced seniors. 


\section{References}

Bennett D.G. (1996), Implications of retirement development in high-amenity non-metropolitan coastal areas, "The Journal of Applied Gerontology", no. 15, pp. 345-360.

Bojanowska E. (2012), Ludzie starsi w rodzinie i społeczeństwie, [in:] J. Hrynkiewicz (ed.), O sytuacji ludzi starych, Rządowa Rada Ludnościowa, Warszawa, pp. 19-32.

Buffel T., Phillipson C. (2011), Experiences of place among older migrants living in inner-city neighbourhoods in Belgium and England, "Diversitéurbaine", no. 11(1), pp. 13-37.

Clark W.A., Lisowski W. (2017), Decisions to move and decisions to stay: Life course events and mobility outcomes, "Housing Studies", no. 32(5), pp. 547-565.

Colsher P.L., Wallach R.B. (1990), Health and other social antecedents of relocation in rural elderly person, "Journal of Gerontology", no. 45(1), pp. 100-136.

Commins P. (2004), Poverty and social exclusion in rural areas: characteristics, processes and research issues, "Sociologia Ruralis", no. 44(1), pp. 60-75.

Cowper D.C., Corcoran E.H. (1989), Older veterans - Possible forerunners of migration: Migration patterns of the elderly veteran population versus the general elderly population, 1960-1980, "Journal of Applied Gerontology", no. 8(4), pp. 451-464.

Cowper D.C., Longino Jr C.F., Kubal J.D., Manheim L.M., Dienstfrey S.J., Palmer J.M. (2000), The retirement migration of US veterans, 1960, 1970, 1980, and 1990, "Journal of Applied Gerontology", no. 19(2), pp. 123-137.

Cuba L., Hummon D. (1993), Constructing a sense of home: Place affiliation and migration across the life cycle, "Sociological Forum", no. 8, issue 4, pp. 547-572.

Day F. A., Barlett J.M. (2000), Economic impact of retirement migration on the Texas Hill Country, "Journal of Applied Gerontology", no. 19(1), pp. 78-94.

EU-SILC (2012), Europejskie badanie warunków życia ludności, Urząd Statystyczny w Poznaniu, Poznań.

Gordon Bennett D. (1996), Implications of retirement development in high-amenity nonmetropolitan coastal areas, "Journal of Applied Gerontology", no. 15(3), pp. 345-360.

Haas W.H., Serow W.J. (1993), Amenity retirement migration process: a model and preliminary evidence, "The Gerontologist", no. 33, pp. 212-220.

Hägerstrand T. (1962), Geographic measurements of migration. Swedish data. Human displacements: Measurements and methodological aspects, Hachette, Monaco, pp. 61-85.

Hogan T. D., Steinnes D.N. (1993), Elderly migration to the Sunbelt: Seasonal versus permanent, "Journal of Applied Gerontology", no. 12(2), pp. 246-260.

Incomes and living conditions of the population in Poland (report from the EU-SILC survey of 2012) (2012), https://stat.gov.pl/en/topics/living-conditions/living-conditions/incomes-and-living-conditions-of-the-population-in-poland-report-from-the-eu-silc-survey-of-2012,1,5.html [accessed: 15.04.2018].

Jankowski G., Pytel S. (2013), Wptyw migracji osób starszych na rynek pracy w obszarach atrakcyjnych turystycznie w Polsce, "Prace Naukowe Uniwersytetu Ekonomicznego we Wrocławiu", no. 304, pp. 253-263.

Kałuża D. (2007), Migracje zagraniczne osób starszych w Polsce, [in:] B. Bugajska (ed.), Życie w starości, Zapol, Szczecin, pp. 287-297.

Kałuża D. (2008), Migracje seniorów, [in:] J.T. Kowaleski, P. Szukalski (eds.), Starzenie się ludności Polski - Między demografia a gerontologia społeczna, Wydawnictwo Uniwersytetu Łódzkiego, Łódź, pp. 71-89.

Kałuża-Kopias D. (2013), Charakterystyka demograficzna imigrantów po sześćdziesiatym roku życia - Polska, "Acta Universitatis Lodziensis. Folia Oeconomica", no. 291, pp. 265-277.

Kałuża-Kopias D. (2014), Specyfika przemieszczeń wewnętrznych osób starszych w Polsce, "Studia Demograficzne", no. 2(166), pp. 97-120. 
King R., Warners A.M., Williams A.M. (1998), International Retirement Migration in Europe, "International Journal of Population Geography", no. 4, pp. 91-111.

Krout J.A., Moen P., Holmes H.H., Oggins J., Bowen N. (2002), Reasons for relocation to a continuing care retirement community, "Journal of Applied Gerontology", no. 21(2), pp. 236-256.

Kurek S. (2006), Migration of the elderly in Poland in 1991-2001, "Bulletin of Geography, Socio-Economic Series”, no. 5, Nicolaus Copernicus University, Toruń, pp. 161-172.

Kurek S. (2011), Double transitions? Regional patterns of population ageing in Poland, "Geografiska Annaler: Series B, Human Geography”, no. 93, issue 2, pp. 163-184.

Kurek S. (2014), Przestrzenne zróżnicowanie przemian demograficznych $w$ Polsce $w$ latach 2002-2011, "Space - Society - Economy", no. 13, pp. 43-74.

La Parra D., Mateo M.A. (2008), Health status and access to health care of British nationals living on the Costa Blanca, Spain, "Ageing and Society", no. 28(1), pp. 85-102.

Lewin K. (1936), Principles of Topological Psychology, McGraw Hill, New York.

Litwak E., Longino C.F. (1987), Migration patterns among the elderly: a developmental perspective, "The Gerontologist", no. 27, pp. 266-272.

Longino Ch.F. (1995), Retirement Migration in America, Vacation Publications, Houston.

Longino Jr C.F., Marshall V.W., Mullins L.C., Tucker R.D. (1991), On the nesting of snowbirds: A question about seasonal and permanent migrants, "Journal of Applied Gerontology", no. 10(2), pp. 157-168.

Marjavaara R., Lundholm E. (2016), Does second-home ownership trigger migration in later life?, "Population, Space and Place", no. 22(3), pp. 228-240.

Moffatt S., Glasgow N. (2009), How useful is the concept of social exclusion when applied to rural older people in the United Kingdom and the United States?, "Regional Studies", no. 43(10), pp. 1291-1303.

Pytel S. (2014a), Atrakcyjność turystyczna miejsc migracji seniorów z województwa śląskiego, "Zeszyty Naukowe Uniwersytetu Szczecińskiego", no. 805, pp. 327-340.

Pytel S. (2014b), Osiedla mieszkaniowe dla seniorów w przestrzeni miast, "Prace Komisji Krajobrazu Kulturowego", no. 25, pp. 155-165.

Pytel S. (2017), Migracje emerytów w Polsce - czynniki, kierunki, konsekwencje, Wydawnictwo Uniwersytetu Śląskiego, Katowice.

Pytel S., Ociepka A. (2016), Aktywność turystyczna seniorów w Polsce, "Zeszyty Naukowe Uniwersytetu Szczecińskiego. Ekonomiczne Problemy Turystyki”, no. 2(34), pp. 83-94.

Pytel S., Szkup R. (2014), Rola atrakcyjności przyrodniczej w migracjach seniorów (na przykładzie województwa śląkiego), [in:] S. Sitek (ed.), "Stare i nowe” problemy badawcze w geografii społeczno-ekonomicznej, zeszyt 5, PTG Oddział Katowicki, Sosnowiec, pp. 117-130.

Quandango J. (2002), Aging and the life course, Pepper Institute on Aging and Public Policy, Florida State University, Tallahassee.

Schiamberg L. B., McKinney K. G. (2003), Factors Influencing Expectations to Move or Age in Place at Retirement Among 40- to 65-Year-Olds, “The Journal of Applied Gerontology”, no. 22, pp. 19-41.

Serow W.J. (1987), Determinants of interstate migration: differences between elderly and non-elderly movers, "Journal of Gerontology", no. 42, pp. 95-100.

Steinnes D.N., Hogan T. D. (1992), Take the money and sun, Elderly migration as a consequence of gains in unaffordable housing market, "Journal of Gerontology", no. 47(4), pp. 197-203.

Śmiłowska T. (2010), Wybrane aspekty warunków życia osób starszych w świetle badań GUS, [in:] D. Kałuża, P. Szukalski (eds.), Jakość życia seniorów w XXI wieku z perspektywy polityki społecznej, Urząd Statystyczny w Łodzi, Łódź, pp. 14-27.

Uren Z., Goldring G. (2007), Migration trends at older ages in England and Wales, "Population Trends", no. 130, pp. 31-41, 
Walford N.S., Kurek S. (2008), A comparative analysis of population ageing in urban and rural areas of England and Wales, and Poland over the last three census intervals, "Population, Space and Place", no. 14(5), pp. 365-386.

Walsh K., Scharf T., Keating N. (2017), Social exclusion of older persons: A scoping review and conceptual framework, "European Journal of Ageing”, no. 14(1), pp. 81-98.

Walters W.H. (2002), Later-life migration in the United States: A review of recent research, "Journal of Planning Literature", no. 17(1), pp. 37-66.

Warnes A.M. (1993), Demographic Ageing: Trends and Policy Response, [in:] D. Noin, R. Woods (eds.), The Changing Population of Europe, Blackwell, Oxford, pp. 82-99.

Warnes A.M. (1994), Permanent and Seasonal International Retirement Migration: The Prospects for Europe', "Netherlands Geographical Studies", no. 173, pp. 69-81.

Warnes A.M., Friedrich K., Kellaher L., Torres S. (2004), The diversity and welfare of older migrants in Europe, "Ageing \& Society", no. 24(3), pp. 307-326.

Warnes A.M., Williams A. (2006), Older migrants in Europe: a new focus for migration studies, "Journal of Ethnic and Migration Studies", no. 32(8), pp. 1257-1281.

Wiseman R.F. (1980), Why Older People Move, "Research on Ageing", no. 2, pp. 141-154.

Wolpert J. (1965), Behavioral Aspects of the Decision to Migrate, "Papers and Proceedings of the Regional Science Association", no. 15.

Zrałek M. (2012), Zaspokojenie potrzeb mieszkaniowych osób starszych. Dylematy i kierunki zmian, [in:] J. Hrynkiewicz (ed.), O sytuacji ludzi starych, Rządowa Rada Ludnościowa, Warszawa, pp. 103-125.

\section{Sytuacja społeczno-ekonomiczna emerytów przed i po migracji}

Streszczenie: Celem artykułu jest ukazanie sytuacji społeczno-ekonomicznej emeryta przed i po migracji. Dzięki takiej diagnozie będzie można wskazać, czy migracja przyniosła pozytywny, czy negatywny skutek. W celu rozpoznania subiektywnych przyczyn migracji przeprowadzono badania ankietowe. Opracowane wyniki badań pozwalają na dokonanie konfrontacji warunków życia przed i po migracji w celu potwierdzenia lub zaprzeczenia koncepcji J. Wolperta (1965) i określenia roli migracji w zaspokajaniu potrzeb emeryta. Przeprowadzone badania potwierdzają podejście Wolperta (1965) mówiące, że podstawowe znaczenie dla zachowań migrantów, również migrantów emerytów, ma użyteczność danego miejsca, czyli suma korzyści, które może uzyskać migrant. Zasobność portfela emerytów po migracji przedstawiała się dobrze, emeryci wskazali, że oszczędne wydatkowanie zasobów ekonomicznych zaspokajało wszystkie potrzeby.

Słowa kluczowe: migracje emerytów, sytuacja ekonomiczna emerytów, sytuacja mieszkaniowa emerytów, sytuacja rodzinna emerytów

JEL: J14 


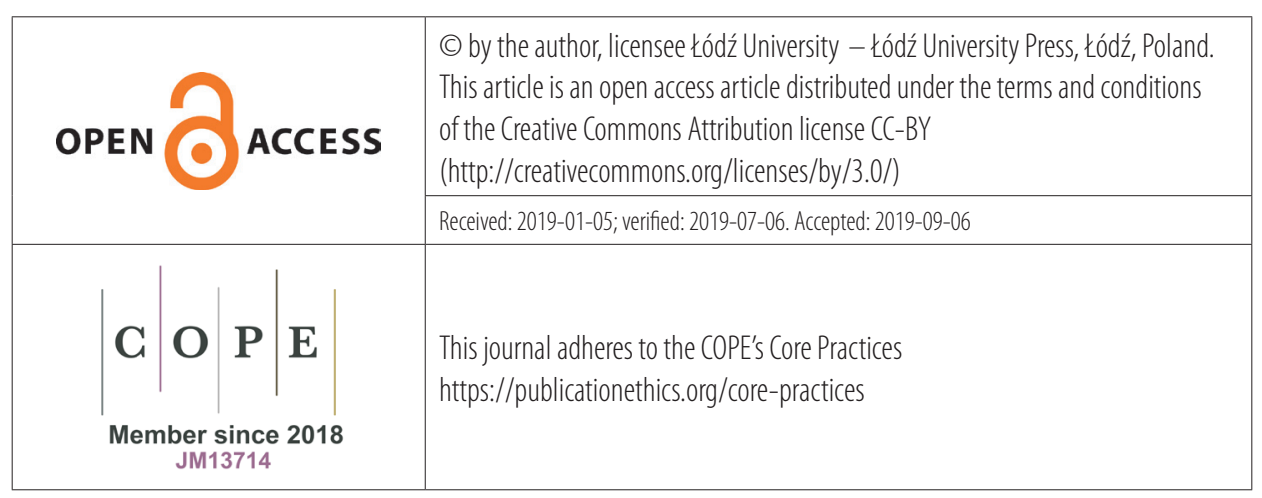

